\title{
Горпинченко К.Н., Кононова Д.А. \\ Статистическая оценка производства прироста живой массы крупного рогатого скота в Краснодарском крае
}

Кубанский государственный аграрный университет им., И. Т. Трубилина

(Россия, Краснодар)

doi:10.18411/spc-14-01-2018-05

idsp: 000001:spc-14-01-2018-05

\section{Аннотация}

В статье представлен анализ производства прироста живой массы крупного рогатого скота в Краснодарском крае, зависимость ее от территориальной зоны. На основе корреляционно-регрессионного анализа оценено влияние различных факторов на изменение себестоимости производства прироста живой массы крупного рогатого скота; сформулированы предложения по увеличению объемов производства продукции выращивания и откорма крупного рогатого скота.

Ключевые слова: скотоводство, прирост, оценка, крупный рогатый скот, себестоимость, производственные затраты.

Основной целью работы является на основе статистического анализ производства продукции выращивания и откорма крупного рогатого скота сформулировать предложения по ее увеличению. В соответствии с целью поставлены и решены следующие задачи: провести статистический анализ состояния и развития производства продукции выращивания и откорма крупного рогатого скота в сельскохозяйственных организациях Краснодарского края; выделить факторы и оценить их влияние на уровень производства продукции выращивания и откорма крупного рогатого скота; внести предложения по увеличению объемов производства продукции выращивания и откорма крупного рогатого скота.

Скотоводство является основной отраслью животноводства, специализирующаяся на разведении крупного рогатого скота для получения молока, говядины, кожевенного сырья, а также в качестве тягловой силы. выделяют несколько направлений: молочное, молочно-мясное, мясо-молочное, мясное [1].

Скотоводство обладает рядом некоторых особенностей как технологических, так и экономических, позволивших выделить его в подотрасль животноводства. Значение этой отрасли для большинства регионов страны определяется не только высокой долей ее в производстве продукции сельского хозяйства, но и влиянием на уровень обеспеченности населения важными продуктами питания, как молоко и мясо. Мясо крупного рогатого скота считается ценным продуктом по вкусовым качествам. Ценность говядины и телятины определяется содержанием белка 15-17\% и жира 1619\%. В мясном балансе страны говядина и телятина занимают более 40\% [3].

Ускоренное развитие мясного скотоводства и выход данной отрасли на самоокупаемость рассматриваются как проблема государственного значения, решение которой позволит научно обоснованно и в интересах всего населения в перспективе удовлетворить платежеспособный спрос на говядину за счет отечественного производства. [2]

Как видно из данных таблицы 1 поголовье крупного рогатого скота в Краснодарском крае за последние пять лет сокращается. В 2016 г. насчитывалось 354 тыс. голов животных, что меньше на 12,2 \% по сравнению с 2012 г. Динамика поголовья животных на выращивании и откорме выявила снижение данного показателя на $11,9 \%$ в сравнении с 2012 г. В то же время среднесуточный привес крупного рогатого скота повысился на $10,3 \%$.

На данный момент первостепенной задачей является восстановление и увеличение поголовья в крае. Сокращение поголовья напрямую связанно с уменьшением числа племенных хозяйств и выбраковка низкопродуктивного поголовья [1]. 
Таблийа 1

Показатели производства продукции выращивания и откорма крупного рогатого скота в сельскохозяйственных организащиях Краснодарского края, 2012-2016 г2.

\begin{tabular}{|c|c|c|c|c|c|c|}
\hline Показатель & \begin{tabular}{|c|}
2012 \\
$\Gamma$.
\end{tabular} & \begin{tabular}{|c|}
2013 \\
$\Gamma$.
\end{tabular} & \begin{tabular}{c|c}
2014 \\
$\Gamma$.
\end{tabular} & $\begin{array}{c}2015 \\
\Gamma .\end{array}$ & \begin{tabular}{|c|}
2016 \\
$\Gamma$.
\end{tabular} & $\begin{array}{l}2016 \text { г. в \% к } \\
2012 \text { г. }\end{array}$ \\
\hline Поголовье крупного рогатого скота, гол & 403 & 378 & 359 & 353 & 354 & 87,84 \\
\hline в т. ч. животные на выращивании и откорме & 251 & 238 & 223 & 218 & 221 & 88,05 \\
\hline $\begin{array}{c}\text { Удельный вес животных на выращивании и откорме в } \\
\text { общем стаде, \% }\end{array}$ & 62,3 & 62,9 & 62,1 & 61,8 & 62,4 & $\mathrm{X}$ \\
\hline $\begin{array}{c}\text { Среднесуточный привес одной головы КРС на откорме и } \\
\text { выращивании, грамм }\end{array}$ & 612 & 632 & 642 & 666 & 675 & $\mathrm{X}$ \\
\hline
\end{tabular}

При анализе влияния зональных различий на производство продукции выращивания и откорма крупного рогатого скота было выявлено, что среднесуточный привес живой массы наибольший в северных районах края и составляет 847 грамм в сутки, наименьший в Южно-Предгорной зоне и составляет 352,5 граммов в сутки. (Таблица 2)

Таблииа 2

Влияние зональных различий на производство продукции выращчвания и откорма крупного рогатого скота в сельскохозяйственных организациях, 2016 г.

\begin{tabular}{|c|c|c|c|c|c|c|}
\hline \multirow{2}{*}{ Зона } & \multirow{2}{*}{$\begin{array}{c}\text { Число } \\
\text { организ } \\
\text { аций }\end{array}$} & \multirow{2}{*}{$\begin{array}{c}\text { Поголовье в } \\
\text { среднем на одну } \\
\text { организацию, } \\
\text { гол. }\end{array}$} & \multirow{2}{*}{$\begin{array}{c}\text { Привес на } 1 \\
\text { гол., ц }\end{array}$} & \multirow{2}{*}{$\begin{array}{c}\text { Среднесуточн } \\
\text { ый привес, г }\end{array}$} & \multicolumn{2}{|c|}{$\begin{array}{c}\text { Производственные } \\
\text { затраты в расчете на }\end{array}$} \\
\hline & & & & & 1 гол. & 1 ц \\
\hline Центральная & 90 & 1148,1 & 2,25 & 614,75 & 573,1 & 111,02 \\
\hline Северная & 100 & 731 & 3,10 & 847 & 330,2 & 150,15 \\
\hline Западная & 25 & 693,2 & 2,27 & 620 & 577,13 & 123,21 \\
\hline Южно-Предгорная & 43 & 187,1 & 1,29 & 352,45 & 685 & 530,23 \\
\hline
\end{tabular}

Также стоить отметить, что при снижении привеса на 1 голову, повышаются производственные затраты в расчете на 1 голову. Так в центральной зоне привес на 1 голову меньше на 0,85 ц, чем в северной зоне, а производственные затраты больше на 139,13 тыс. рублей. Таким образом можно проследить зависимость себестоимости 1 центнера прироста живой массы от территориальной зоны.

Группировка сельскохозяйственных организаций по приросту живой массы крупного рогатого скота установила, что с увеличением группировочного признака производственные затраты снижаются. Так, в хозяйствах третьей группы с мясной продуктивностью 1, 641 ц/гол производственные затраты на одну голову составили 29 тыс. руб., что ниже на $11,8 \%$, чем в организациях первой группы со средним приростом живой массы 0,361 ц/гол. Кроме этого, от первой к третьей группе снижается уровень трудоемкости и убыточность производства.

Таблийа 3

Группировка сельскохозяйственных организаций по приросту живой массы крупного рогатого скота на 1 гол, из за 2016 г.

\begin{tabular}{|c|c|c|c|c|c|c|c|c|}
\hline \multirow{2}{*}{$\begin{array}{c}\text { Группы } \\
\text { хозяйств } \\
\text { по } \\
\text { приросту } \\
\text { живой } \\
\text { массы } \\
\text { КРС, ц/гол }\end{array}$} & \multirow[b]{2}{*}{$\begin{array}{c}\text { Число } \\
\text { хозяй } \\
\text { ств в } \\
\text { группе }\end{array}$} & \multirow{2}{*}{$\begin{array}{c}\text { Прирост } \\
\text { живой } \\
\text { массы КРС } \\
\text { в среднем } \\
\text { по группе, } \\
\text { ц/гол }\end{array}$} & \multicolumn{2}{|c|}{$\begin{array}{l}\text { Производственные } \\
\text { затраты, тыс. руб. }\end{array}$} & \multirow[b]{2}{*}{$\begin{array}{l}\text { Трудоемк } \\
\text { ость, } \\
\text { чел.-час/ц }\end{array}$} & \multicolumn{2}{|c|}{ Убыток, тыс. руб. } & \multirow[b]{2}{*}{$\begin{array}{c}\text { Уровень } \\
\text { убыточн } \\
\text { ости, \% }\end{array}$} \\
\hline & & & на 1 гол & на 1 ц & & на 1 гол & на 1 ц & \\
\hline $\begin{array}{c}0,041- \\
0,681 \\
\end{array}$ & 21 & 0,361 & 132,6 & 382,1 & 434 & 640 & 286 & 89,54 \\
\hline $\begin{array}{c}0,681- \\
1,321\end{array}$ & 7 & 1,001 & 137,6 & 121,9 & 101 & 81,5 & 25,1 & 81,19 \\
\hline $\begin{array}{c}1,321- \\
1,961\end{array}$ & 2 & 1,641 & 124,6 & 41,79 & 60 & 123 & 54,2 & 101,03 \\
\hline
\end{tabular}


Одним из результативных показателей производства является себестоимость продукции, которая оказывает влияние на эффективность производства, характеризует использование ресурсного потенциала. Поэтому очень важно рассмотреть постатейный анализ себестоимости, изучить влияние различных факторов на общее ее изменение. Согласно данным таблицы 4 в 2016 г. по сравнению с 2015 г. производственная себестоимость 1 ц прироста живой массы прироста крупного рогатого скота повысилась в среднем по Краснодарскому краю на 3,8 \%. В том числе в результате роста затрат на оплату труда себестоимость 1 ц прироста увеличилась на $1,7 \%$, а повышение затрат на корма на 6,2 \% увеличило удельные производственные затраты на 3,1 \%. Однако, снижение затрат на содержание основных средств, составляющее 20,9 $\%$, способствовало сокращению себестоимости на $1,9 \%$.

Таблица 4

Влияние статей затрат на изменение себестоимости производства прироста живой массы крупного рогатого скота

\begin{tabular}{|c|c|c|c|c|c|c|c|}
\hline \multirow[b]{2}{*}{ Статья затрат } & \multicolumn{2}{|c|}{2015 г. } & \multicolumn{2}{|c|}{2016 г. } & \multicolumn{2}{|c|}{ Изменение (+,-) } & \multirow{2}{*}{$\begin{array}{c}\text { Влияние } \\
\text { статей затрат } \\
\text { на общее } \\
\text { изменение } \\
\text { себестоимости } \\
, \%\end{array}$} \\
\hline & руб./ц & $\%$ & руб./ц & $\%$ & руб./ц & $\%$ & \\
\hline $\begin{array}{c}\text { Оплата труда с } \\
\text { отчислениями на } \\
\text { социальные нужды }\end{array}$ & 170 & 15,6 & 170,8 & 16,7 & 0,8 & 0,47 & 0,07 \\
\hline $\begin{array}{c}\text { Материальные затраты } \\
\text { в т. ч. корм }\end{array}$ & 553,13 & 50,84 & 530,1 & 51,96 & $-23,03$ & 4,16 & 2,12 \\
\hline электроэнергия & 30,0 & 2,77 & 27,4 & 2,7 & $-2,6$ & 8,67 & 0,24 \\
\hline нефтепродукты & 21,87 & 2,03 & 21,2 & 2,08 & $-0,67$ & 3,06 & 0,06 \\
\hline $\begin{array}{c}\text { Содержание основных } \\
\text { средств }\end{array}$ & 101,12 & 9,29 & 72,2 & 7,07 & $-28,92$ & $-28,6$ & 2,66 \\
\hline Прочие затраты & 211,88 & 19,47 & 198,9 & 19,4 & $-12,98$ & $-6,12$ & 1,19 \\
\hline $\begin{array}{l}\text { Себестоимость } \\
1 \text { ц прироста }\end{array}$ & 1088 & 100 & 1020 & 100 & $-67,4$ & $-6,25$ & $\mathrm{X}$ \\
\hline
\end{tabular}

В структуре производственных затрат половина приходится на затраты на корма. Значительный удельный вес занимают затраты на оплату труда, доля которых в общей себестоимости снизилась с 15,6 \% в 2015 г. до 11,2 \% в 2016 г.

В результате выборочного наблюдения нами отобрано 30 сельскохозяйственных организаций центральной зоны Краснодарского края. Расчет обобщающих характеристик установил, средняя себестоимость 1 ц прироста живой массы крупного рогатого скота составила 17408 руб./ц и в среднем между предприятиями себестоимость колеблется от 11310,8 руб./ц до 23505,2 руб./ц. Коэффициент вариации составил 35,5\%, что свидетельствует о больших различиях в себестоимости производства 1 ц прироста живой массы крупного рогатого скота между предприятиями.

Распределение сельскохозяйственных организаций по данному признаку является несимметричными $($ Ка $=0,730)$ и островершинным $(Э=-0,348)$.

Линейное уравнение множественной регрессии в натуральной форме имеет вид:

$$
\hat{y}=b_{0}+b_{1} x_{1}+b_{2} x_{2}+b_{3} x_{3}+b_{4} x_{4}
$$

Где у - это себестоимость производства 1 ц прироста живой массы крупного рогатого скота, руб./ ц; b0 - это свободный член уравнения, $b_{1}, b_{2}, b_{3}$ и $b_{4}$ - это коэффициенты множественной регрессии.

Линейное уравнение множественной регрессии имеет вид:

$$
\hat{y}=22544,4+16799,1 x_{1}+38,49 x_{2}+160,08 x_{3}+21,94 x_{4}
$$

$\mathrm{x}_{1}$ - прирост живой массы крупного рогатого скота, ц/гол.;

$\mathrm{x}_{2}$ - прямые затраты труда на 1 ц, чел.-час; 
$\mathrm{x}_{3}$ - доля затрат на корма в общих затратах, \%;

$\mathrm{x}_{4}$ - оплата труда 1 чел.-час, руб.

Коэффициенты множественной регрессии показывают, что при увеличении прироста живой массы крупного рогатого скота ц/гол себестоимость производства 1 ц прироста живой массы в среднем увеличивается на 0,234 ц/гол, а при росте затрат труда на 1 гол на 1 чел-час - затраты на 1 ц в среднем повысятся на 1,877 ц/гол.

По абсолютной величине коэффициентов можно сделать вывод об относительной силе влияния факторов на изменение себестоимости 1 ц прироста. На себестоимость большее влияние оказывает прирост живой массы на одну голову и затраты на корма. Также стоить отметить, что при увеличении прироста живой массы крупного рогатого скота на $1 \%$, себестоимость 1 ц прироста живой массы увеличивается в среднем на 0,486\%, исключив влияние других факторов. Если увеличить расход на корма на $1 \%$, то себестоимость 1 ц прироста в среднем увеличится на $0,531 \%$. Анализ исследуемых данных показал, что на себестоимость производства 1 ц прироста живой массы крупного рогатого скота статистически значимое влияние оказывают представленные факторы.

В настоящее время говядину в основном получают от скота молочных и молочно-мясных пород. Отечественный и зарубежный опыт показывает, что вывести производство говядины на должный уровень возможно при правильном сочетании интенсивного молочного и мясного скотоводства. Поскольку мясное скотоводство, как отдельная специализированная отрасль в Российской федерации плохо развита, увеличение мясного потенциала скота пород молочного направления играет важную роль в решении мясной проблемы. Краснодарский край занимает последнее место по обеспеченности пастбищными угодьями, приходящимися на 1 голову крупного рогатого скота. Это связано с тем, что пашни имеют высокую долю в общей структуре сельскохозяйственных угодий. Это также является одной из причин слабого развития производства мяса КРС на базе откорма животных мясных пород в нашем регионе. Увеличить производство говядины можно за счет повышения продуктивности крупного рогатого скота при выращивании и откорме, уменьшении возраста реализации и доведения животных до более высоких убойных кондиций.

В заключение важно сказать, что основной проблемой при выращивании и откорме крупного рогатого скота является перерасход используемых ресурсов, наибольший перерасход наблюдается по кормовым и трудовым ресурсам, что отрицательно сказывается на эффективном ведении отрасли. Из этого следует, что определяющим фактором в повышении эффективности производства продукции выращивания и откорма КРС является совершенствование системы ресурсосбережения. Негативным следствием сложившейся ситуации при использовании кормовых ресурсов является то, что при дефиците собственных концентратов предприятиям, занимающимся мясным скотоводством, необходимо закупать концентраты и другие виды кормов, цена на которые в 2-3 раза выше по сравнению с кормами собственного производства. Поэтому хозяйствам, базирующимся на откорме крупного рогатого скота, было бы весьма выгоднее самим производить концентрированные корма и тем самым затраты на корма значительно бы снизились, следовательно снизилась бы себестоимость 1 центнера прироста живой массы.

$$
\text { *** }
$$

1. Горпинченко, К. Н. Проблемы и перспективы развития скотоводства в Краснодарском крае / К. Н. Горпинченко, Е. А. Горпинченко, Д. А. Алексеева //Научный диалог: Экономика и менеджмент. Сборник научн. трудов по мат. межд. научно-практич. конф. , 8 февраля 2017 г. - Самара: Общественная наука, 2017. - С. 10-14.

2. Грибов, А. В. Формирование устойчивой кормовой базы как определяющий фактор повышения эффективности мясного скотоводства / А. В. Грибов // Проблемы экономики. - 2014. - №1 (18). - С. 34-40.

3. Зелепухин, А. Повышение эффективности использования производ- ственного потенциала в скотоводстве [Текст] / А. Зелепухин // АПК: экономика, управление. - 2001. - № 8. - С. 3-7. 